\title{
Inhibition Effects of Phenolic Compounds on Human Serum Paraoxonase-1 Enzyme
}

\author{
Cüneyt TÜRKEŞ ${ }^{1 *}$
}

\begin{abstract}
Metabolic processes in living organisms are closely related to the catalytic activity of enzymes. Inhibition or induction of enzymes leads to toxicities and metabolic interactions. This study aims to contribute to the growing drug design field by studying PON1-phenolic compound interactions. For this purpose, the paraoxonase- 1 enzyme was purified from fresh human serum by using rapid and different chromatographic techniques. Additionally, it was investigated the inhibitory effects of some phenolic substances on the PON1 and was found that the purified enzyme had the molecular weight of $43 \mathrm{kDa}$ and the specific activity of $3945.15 \mathrm{EU} \mathrm{mg}^{-1}$. These compounds showed potent inhibition against PON1, especially homovanillic acid exhibited a significant inhibition profile against PON1 with an $\mathrm{IC}_{50}$ value of $13.84 \pm 0.08 \mathrm{mM} . K_{i}$ constants were $6.10 \pm 0.26 \mathrm{mM}$ for homovanillic acid and $16.96 \pm 0.76 \mathrm{mM}$ for phloridzin dihydrate. Homovanillic acid had competitive inhibition while the phloridzin dihydrate inhibited the PON1 as non-competitive. Also, molecular docking computations were performed by using the Glide XP mode. Glide energy of the homovanillic acid determined to be $-23.95 \mathrm{kcal} \mathrm{mol}^{-1}$.
\end{abstract}

Keywords: Paraoxonase, HDL, chromatography, inhibition, phenolic compound, molecular docking.

\section{Fenolik Bileşiklerin İnsan Serum Paraoksonaz-1 Enzimi Üzerindeki İnhibisyon Etkileri}

ÖZET: Canlı organizmalardaki metabolik süreçler, enzimlerin katalitik aktivitesi ile yakından ilişkilidir. Enzimlerin inhibisyonu veya indüksiyonu toksisiteye ve metabolik etkileşimlere yol açar. $\mathrm{Bu}$ çalışma, PON1-fenolik madde etkileşimlerini inceleyerek büyüyen ilaç tasarım alanına katkıda bulunmayı amaçlamaktadır. Bu amaçla, paraoksonaz-1 enzimi, hızlı ve farklı kromatografik teknikler kullanılarak taze insan serumundan saflaştırılmıştır. Ek olarak, bazı fenolik bileşiklerin PON1 üzerindeki inhibisyon etkileri araştırılmış ve saflaştırılan enzimin $3945.15 \mathrm{EU} \mathrm{mg}^{-1}$ protein spesifik aktiviteye ve $43 \mathrm{kDa}$ molekül ağırlığına sahip olduğu bulunmuştur. Bu bileşikler PON1'e karş1 güçlü inhibisyon gösterdiler, özellikle homovanilik asit $13.84 \pm 0.08$ mM'lık bir $\mathrm{IC}_{50}$ değeri ile PON1'e karş1 önemli bir inhibisyon profili sergiledi. $K_{i}$ sabitleri homovanillik asit için $6.10 \pm 0.26 \mathrm{mM}$ ve phloridzin dihidrat için $16.96 \pm 0.76 \mathrm{mM}$ idi. Homovanilik asit yarışmalı inhibisyona sahipken, phloridzin dihidrat PON1'i yarışmasız olarak inhibe etmiştir. Ayrıca, moleküler yerleştirme hesaplamaları Glide XP modu kullanılarak gerçekleştirilmiştir. Homovanilik asitin glide enerjisi $-23.95 \mathrm{kcal} \mathrm{mol}^{-1}$ olarak belirlenmiştir.

Anahtar kelimeler: Paraoksonaz, HDL, kromatografi, inhibisyon, fenolik madde, moleküler yerleştirme

\footnotetext{
${ }^{1}$ Cüneyt TÜRKEŞ (Orcid ID: 0000-0002-2932-2789), Department of Biochemistry, Faculty of Pharmacy, Erzincan Binali Y1ldırım University, 24100, Erzincan, Turkey

Sorumlu Yazar/Corresponding Author: Cüneyt TÜRKEŞ, e-mail: cuneyt.turkes@ outlook.com 


\section{INTRODUCTION}

HDL-associated

paraoxonase

(organophosphate hydrolase; PON1) is responsible for reducing the oxidation of $\mathrm{LDL}$ by metabolizing oxidized phospholipids. PON1 is also accountable for most of the antiinflammatory, and antioxidative effects of HDL (Mackness et al., 1993; Teiber et al., 2018). Cardiovascular diseases are highly related to low HDL. It has been shown that treatments for increasing plasma HDL cholesterol in humans especially support regression of cardiovascular diseases and reduced the progression of atherosclerosis. HDL also has acts such as the inhibition of proteinases in the plaque protecting regular endothelial function (Kontush and Chapman, 2006). All functions of HDL which subscribe to its protective effects act directly attenuating risk of coronary heart diseases. The reverse transfer of cholesterol from cells and the easy transport of macrophages in the artery wall are the antiatherogenic properties of HDL.

PON, which is a calcium-dependent esterase, has the ability to hydrolyze paraoxon, a metabolite of the insecticide parathion. PON1 detoxifies various nerve agents and also hydrolyzes metabolites of a number of other insecticides (Costa et al., 1999; Manco et al., 2018). Additionally, PON1 is an esterase which has a molecular mass of approximately 43-45 $\mathrm{kDa}$ and consists of 354 amino acids (Furlong et al., 1989; Hassett et al., 1991). Decreasing PON1 activity has been reported to be a potent risk factor for coronary events rather than genetic polymorphisms. PON1 is the most dominant antioxidant enzyme, among some other HDLassociated proteins such as apolipoprotein A1, platelet-activating factor acetyltransferase, and lecithin-cholesterol acyltransferase (Mackness and Durrington, 1995).

Phenolic compounds are a critical group produced by plants as secondary metabolites. Plants synthesize phenolic substances to defend against pathogens, protection against ultraviolet light and to regulate metabolic activities (Velderrain-Rodríguez et al., 2014). Phenolic substances are classified according to with respect to attached substituents and the number of phenolic rings (Manach et al., 2005). Also, the position and number of these components affect biological function, significantly (Fraga et al., 2010). It is determined that dietary components, including phenolic compounds, influence drug metabolizing enzymes and can cause important toxicological results (Middleton et al., 2000; Surh, 1998). The significance of these compounds is rising, because of the increasing frequency of various diseases such as coronary artery disease, cancer, Alzheimer's disease, and diabetes, which are develop linked to their eating habits in recent times (Gutiérrez-Grijalva et al., 2016; Kuzu et al., 2018).

Homovanillic acid belongs to the class of phenolic acids known as hydroxyphenylacetic acids and is a strong radical scavenger (Tuck and Hayball, 2002). Phloridzin dihydrate (Phloretin 2'-glucoside), a natural anti-diabetic molecule, is the flavonoid glucoside as a member of dihydrochalcone family (Wang et al., 2007). This flavonoid has different biological activities (Masumoto et al., 2009).

Metabolic processes in living organisms are closely related to the catalytic activity of enzymes. Changes in enzyme activity can cause various diseases. Thus, compounds which inhibit enzyme activity must be beneficial therapeutic agents (Copeland, 2004; Copeland, 2013; Robertson, 2005). This study set out to the in vitro effects of some phenolic substances, such as homovanillic acid and phloridzin dihydrate (Figure 1) on PON1 enzyme activity. For this reason, PON1 was purified from human serum by using simple and rapid methods, easily. Moreover, to support the experimental results, molecular docking studies also were performed. 
<smiles>COc1cc(CC(=O)O)ccc1O</smiles>

Homovanillic acid<smiles>O=C(CCc1ccc(O)cc1)c1c(O)cc(O)cc1O[C@@H]1O[C@H](CO)[C@@H](O)[C@H](O)[C@H]1O</smiles>

Phlorizin dihydrate

Figure 1. The molecular structures of the homovanillic acid and phloridzin dehydrate

\section{MATERIALS AND METHODS}

\section{General Information}

The chromatography media, including IEX and SEC resins, and all chemical agents were purchased from Sigma-Aldrich Chemie. The chemical substances used for preparing the test solutions were of analytical grade. Human serum samples were provided from Research Hospital of Erzincan Binali Yıldırım University (Erzincan, Turkey).

\section{Paraoxonase Activity Determination}

The process of paraoxonase enzyme activity was carried out as in our previous research, spectrophotometrically (Türkeş et al., 2014). Enzymatic activity was computed by using the molar absorptivity coefficient $\left(\varepsilon=18,290 \mathrm{M}^{-1} \mathrm{~cm}^{-1}\right.$ ) of p-nitrophenol at $412 \mathrm{~nm}$ (Figure 2) (Renault et al., 2006). The EU is the amount of the enzyme that catalyzes the reaction of 1 micromole of substrate per minute under standard conditions at $25^{\circ} \mathrm{C}$ (Mackness and Durrington, 1995).

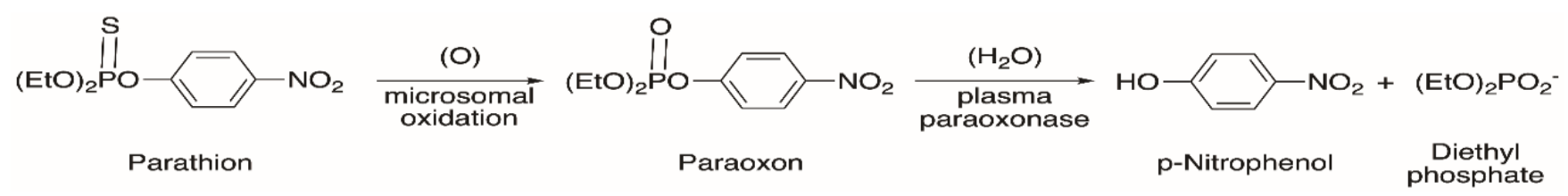

Figure 2. The reaction for which paraoxonase enzyme was named (Furlong, 2008)

\section{Ammonium Sulfate Precipitation of Proteins}

Ammonium sulfate method (60-80\%) was used in for precipitation of enzymes by pulling water molecules away according to the procedure used as our previous papers (Akbaba et al., 2013). The precipitate obtained after the precipitation of approx. $30 \mathrm{~mL}$ of fresh human serum was centrifuged at $12,500 \mathrm{x} g$ for 30 minutes and dissolved in phosphate buffer solution at $100 \mathrm{mM}$, pH 7.0 (Sinan et al., 2006).

\section{Ion Exchange Chromatography (IEX)}

The enzyme precipitate, which had been dialyzed in the presence of $1 \mathrm{mM}$ Na-phosphate buffer $\left(\mathrm{pH} \mathrm{7.0)}\right.$ at $4^{\circ} \mathrm{C}$, was loaded onto IEX column (DEAE anion exchanger, separation range 30 to $100 \mathrm{kDa}$ for $\mathrm{A}-50$ ), which had been equilibrated with binding buffer $(100 \mathrm{mM} \mathrm{Na}$ phosphate buffer, $\mathrm{pH}$ 7.0). The column (30 mm $\times 30 \mathrm{~cm}$ in dimensions) was washed with the same buffer and then elution was achieved using an increasing salt gradient of $0-1.5 \mathrm{M} \mathrm{NaCl}$. The qualitative protein analysis result and paraoxonase activity were recorded for each tube (Türkeş et al., 2013).

\section{Size Exclusion Chromatography (SEC)}

Size exclusion chromatography (i.e., gel filtration, GF) was performed after ion exchange 
chromatography since the buffer composition doesn't affect the final separation. Eluates obtaining from the IEX column were loaded onto the SEC column (separation range 4 to 150 $\mathrm{kDa}$ for Sephadex G-100) which is $20 \mathrm{~mm} \times 60$ $\mathrm{cm}$ in dimensions which had been equilibrated with binding buffer (100 mM Na-phosphate buffer, $\mathrm{pH}$ 7.0). Desorption was performed with the same buffer, isocratically (Alim and Beydemir, 2016). The effluents were analyzed for both qualitative protein analysis and paraoxonase activity.

\section{Quantitative Protein Determination}

After mixing, the mixture (i.e., Bradford reagent with the protein sample) changed to blue color and a change of the absorption from 465 $\mathrm{nm}$ to $595 \mathrm{~nm}$ occurred. Bovine serum albumin was utilized as the standard in Bradford Protein Assay, a spectrophotometric method (Bradford, 1976; Aslan et al, 2018).

\section{SDS-PAGE Study}

The molecular weight, purity, and subunit composition of the enzyme were controlled with Laemmli SDS-PAGE (3-8\%) technique, an analytical method (Laemmli, 1970; Türkeş et al., 2016). Prestained protein standard (size range from 10 to $180 \mathrm{kDa}$ ) was used as the molecular mass standard.

\section{Inhibition Studies}

For the specification of the inhibition impacts of homovanillic acid and phloridzin dihydrate on the PON enzyme, the Activity\%[Phenolic compound] graphs were drawn (Türkeş et al., 2015). The $\mathrm{IC}_{50}$ values were calculated from these graphs for homovanillic acid and phloridzin dihydrate. Lineweaver-Burk $\left.\left(\left(E U \mathrm{ml}^{-1}\right)^{-1} \text {-[Paraoxon }\right]^{-1}\right)$ curves were utilized to determine inhibition parameters, such as inhibition type, $K_{i}$, and Vmax (Lineweaver and Burk, 1934).

\section{Molecular Docking Analysis}

The docking study of homovanillic acid was carried out using Schrödinger-Glide. PON1 (PDB ID: 3SRE), which was taken from PDB (www.rscb.org), was prepared utilizing the protein preparation wizard (Greenwood et al., 2010; Shelley et al., 2007). The ligand file was acquired from the NCBI PubChem database (CID 1738 for homovanillic acid). Then, LigPrep was used to prepare the ligand and the structure was optimized utilizing the OPLS3e force field (Sastry et al., 2013). Also, 2hydroxyquinoline (2-HQ) was used as a reference inhibitor agent for 3SRE. The ligand docking was done flexibly using extra precision (XP) mode of Glide module (Friesner et al., 2004; Halgren et al., 2004) (Glide, Schrödinger 2018-4, LLC, New York, NY, 2018).

Table 1. Purification steps of the paraoxonase-1

\begin{tabular}{|c|c|c|c|c|c|c|c|c|}
\hline Purification steps & 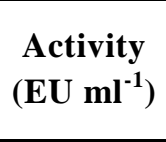 & $\begin{array}{c}\text { Total } \\
\text { volume } \\
\text { (ml) }\end{array}$ & $\begin{array}{c}\text { Protein } \\
\left(\mathrm{mg} \mathrm{m}^{-1}\right)\end{array}$ & $\begin{array}{c}\text { Total } \\
\text { protein } \\
\text { (mg) }\end{array}$ & $\begin{array}{c}\text { Total } \\
\text { activity } \\
\text { (EU) }\end{array}$ & 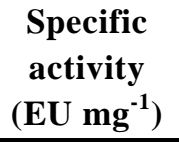 & $\begin{array}{c}\text { Yield } \\
(\%)\end{array}$ & $\begin{array}{c}\text { Purification } \\
\text { fold }\end{array}$ \\
\hline Serum & 105.3 & 30 & 6.40 & 192.00 & 3160.20 & 16.46 & 100.00 & 1.00 \\
\hline Ammonium sulfate precipitation & 103.2 & 20 & 4.60 & 92.00 & 2063.06 & 22.42 & 65.28 & 1.36 \\
\hline Ion exchange chromatography & 72.9 & 15 & 0.20 & 3.00 & 1093.49 & 364.50 & 34.60 & 22.15 \\
\hline Size exclusion chromatography & 67.1 & 10 & 0.02 & 0.17 & 670.68 & 3945.15 & 21.22 & 239.69 \\
\hline
\end{tabular}

\section{RESULT AND DISCUSSION}

All of the disease cases are caused by dysregulated enzyme activities (Copeland,
2004). In some tissues with diseases, the in vivo or in vitro measuring of enzyme activity, and then imaging with inhibition of drug practice is 
utilized as a pharmacokinetic, and pharmacodynamic marker. There are many enzymes in xenobiotic metabolism, and the most significant ones are paraoxonases, cholinesterases, and carboxylesterases (Klaassen and Watkins, 1996). Recently, some research has been conducted on PON1, which has been known to play an important role in the development of coronary heart diseases. However, there are only a few scientific data concerning the effects of chemical agents on PON1 activity in the scientific literature. Therefore, this study provides an important contribution to the researches on PON1-drug interactions.

Table 2. $\mathrm{IC}_{50}$ values and $K_{i}$ constants for the compounds

\begin{tabular}{cccc}
\hline Inhibitor & $\mathbf{I C}_{\mathbf{5 0}}(\mathbf{m M})$ & $\boldsymbol{K}_{\boldsymbol{i}}(\mathbf{m M})$ & Inhibition type \\
\hline Homovanillic acid & $13.84 \pm 0.08$ & $6.10 \pm 0.26$ & Competitive \\
Phloridzin dihydrate & $14.62 \pm 0.24$ & $16.96 \pm 0.76$ & Non-competitive \\
\hline
\end{tabular}

The assay results were presented as mean \pm standard deviation.

In the previous study, for illustrate, scientists investigated the effects of some metals on PON1 activity. They found that $\mathrm{Pb}^{2+}, \mathrm{Cr}^{2+}$, $\mathrm{Fe}^{2+}$, and $\mathrm{Zn}^{2+}$ were effective inhibitors for PON1, and $\mathrm{IC}_{50}$ values were $0.838,1.991,3.960$, and $7.410 \mathrm{mM}$, respectively, and $K_{i}$ constants were in the range of $0.639-4.604 \mathrm{mM}$. In the same study, they also identified that $\mathrm{Pb}^{2+}$ and $\mathrm{Fe}^{2+}$, and $\mathrm{Zn}^{2+}$ showed competitive inhibition;
$\mathrm{Cr}^{2+}$, non-competitive; and $\mathrm{Zn}^{2+}$, uncompetitive inhibition at the end of the research (Ekinci and Beydemir, 2010). In a study on PON1 activity was reviewed the effects of various pesticides, such as dichlorvos, imidacloprid, lambda cyhalothrin, and fenoxaprop-p-ethyl. As a result of the study, $\mathrm{IC}_{50}$ values were found to be $0.0103,0.0690,0.1570$, and $0.2000 \mu \mathrm{M}$, respectively (Cebeci et al., 2014).

Table 3. XP Glide docking results for homovanillic acid

\begin{tabular}{ccccccc}
\hline Inhibitor & $\begin{array}{c}\text { PubChem } \\
\text { CID }\end{array}$ & $\begin{array}{c}\text { Glide } \\
\text { GScore } \\
\left(\mathrm{kcal} \mathrm{mol}^{\mathbf{1}}\right)\end{array}$ & $\begin{array}{c}\Delta \mathbf{G} \\
\mathbf{v d W} \\
\left(\mathrm{kcal} \mathrm{mol}^{\mathbf{1}}\right)\end{array}$ & $\begin{array}{c}\Delta \mathbf{G} \\
\mathbf{C o u l o m b} \\
\left(\mathrm{kcal} \mathrm{mol}^{\mathbf{1}}\right)\end{array}$ & $\begin{array}{c}\text { Glide } \\
\text { energy } \\
\left(\mathrm{kcal} \mathrm{mol}^{\mathbf{1}}\right)\end{array}$ & $\begin{array}{c}\text { Glide } \\
\text { model } \\
\left(\mathrm{kcal} \mathrm{mol}^{\mathbf{1}}\right)\end{array}$ \\
\hline Homovanillic acid & 153921 & -3.29 & -15.48 & -8.47 & -23.95 & -28.15 \\
\hline
\end{tabular}

In our previous study, it was investigated in vitro inhibitory effects of some bromophenols, which are between the natural organohalogen agents, on PON1 activity. $\mathrm{IC}_{50}$ values of these bromophenols were found ranging between 0.123 and $1.212 \mathrm{mM}$ (Akbaba et al., 2013). Additionally, in our previous studies, we researched that the in vitro effects of various nucleoside analogues (e.g., 5-fluorouracil, and acyclovir, and gemcitabine hydrochloride) (Türkeş et al., 2013), certain calcium-channel antagonists including, amlodipine besylate, isradipine, nifedipine, and nitrendipine (Türkeş et al., 2014), some antibacterial drugs, such as, ceftizoxime sodium, cefotaxime sodium, cefepime hydrochloride, levofloxacin hemihydrate, and moxifloxacin hydrochloride (Türkeş et al., 2015), and diverse antineoplastic 
drugs, (bevacizumab, and palonosetron hydrochloride) (Türkeş et al., 2016) on enzyme activity of human serum PON1. According to the findings of these researches, some chemical compounds, such as metals and pesticides, have

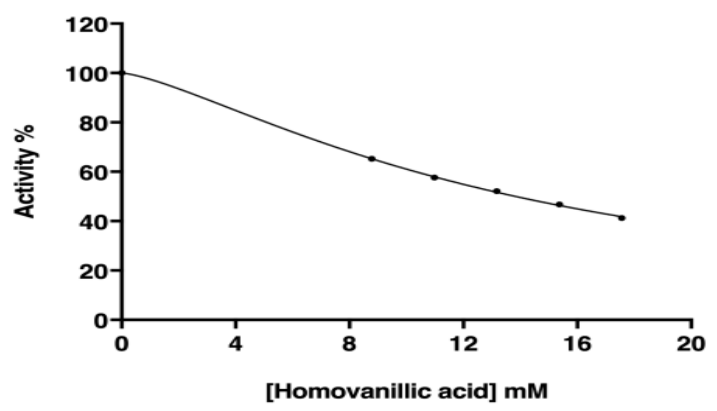

(A) shown inhibition effect on PON1 at very low concentrations and exhibited several types of inhibition. In addition, even though most of the drugs used were in therapeutic doses, they strongly inhibited PON1.

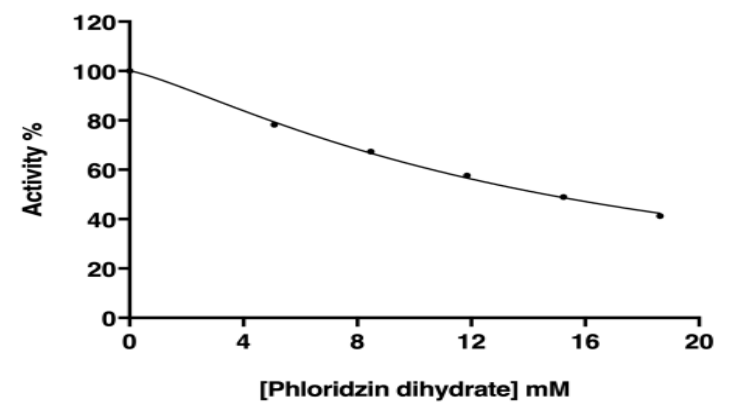

(B)

Figure 3. In vitro effect of phenolic compounds

In this study, it was utilized the similar procedure used by our group in previous studies and purified human serum PON1 in three simple and rapid steps. The purification resulted in as a $21.22 \%$ yield, $3945.15 \mathrm{EU} \mathrm{mg}^{-1}$ proteins specific activity, and approx. 239-fold (Table 1). Single protein band was obtained for this enzyme and the molecular weight (MW) of the enzyme was computed as $43 \mathrm{kDa}$ by SDS-PAGE. These results match those found in earlier studies (Alim and Beydemir, 2016; Alim et al., 2017; Alım et al., 2018; Beydemir and Demir, 2017; Ekinci and Beydemir, 2009; Ekinci et al., 2010; Pla et al., 2007; Sinan et al., 2006).

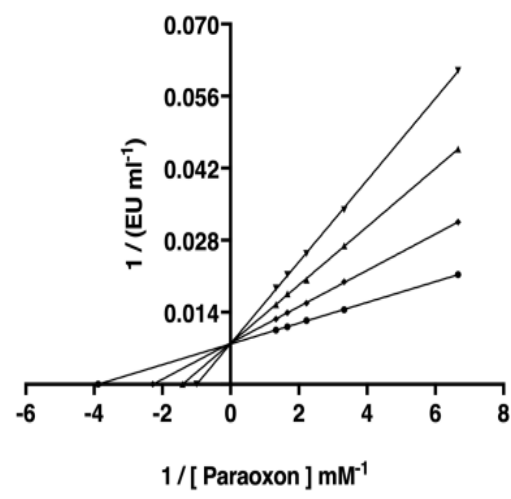

(A)

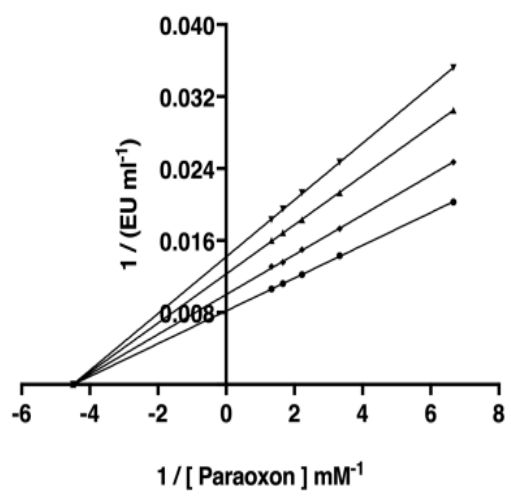

$\rightarrow[$ Control]

$\rightarrow[1-1]: 5.08 \mathrm{mM}$

$\leftarrow[1-2]: 8.47 \mathrm{mM}$ $\rightarrow[1-3]: 11.85 \mathrm{mM}$

Figure 4. Lineweaver-Burk curves. (A) Homovanillic acid and (B) Phloridzin dehydrate

In the same study, we also focused on the in vitro inhibition role of some phenolic substances including homovanillic acid and phloridzin dihydrate on PON1 enzyme activity. $\mathrm{IC}_{50}$ values were $13.84 \pm 0.08 \mathrm{mM}$ for homovanillic acid, and $14.62 \pm 0.24 \mathrm{mM}$ for 
phloridzin dihydrate (Table 2 and Figure 3 ). $K_{i}$ constants for homovanillic acid, and phloridzin dihydrate were calculated to be $6.10 \pm 0.26 \mathrm{mM}$ and $16.96 \pm 0.76 \mathrm{mM}$, respectively (Table 2, Figure 4). These results suggest that homovanillic acid interacts binding with the residues in the PON1's active site and shows competitive inhibition. To verify experimental results, molecular docking studies were implemented by using the Glide software. Molecular docking result of homovanillic acid conducted using Glide-XP protocol is depicted in Table 3. Homovanillic acid displayed Glide
XP score of $-3.29 \mathrm{kcal} \mathrm{mol}^{-1}$, Glide energy of $23.95 \mathrm{kcal} \mathrm{mol}^{-1}$ and a Glide emodel score of $28.15 \mathrm{kcal} \mathrm{mol}^{-1}$. Residues Tyr71, His 184, $\mathrm{PO}_{4} 1358$, and Phe222 were found strongly interacting with the homovanillic acid (Figure 5). Binding energies in the 3SRE-homovanillic acid interaction has shown to fit best the ligand binds with PON1 and supported obtained results during biological activities analyses. Also, since the inhibition mechanism of phloridzin dihydrate has non-competitive, this compound could be linked to anywhere except the active site of the enzyme.

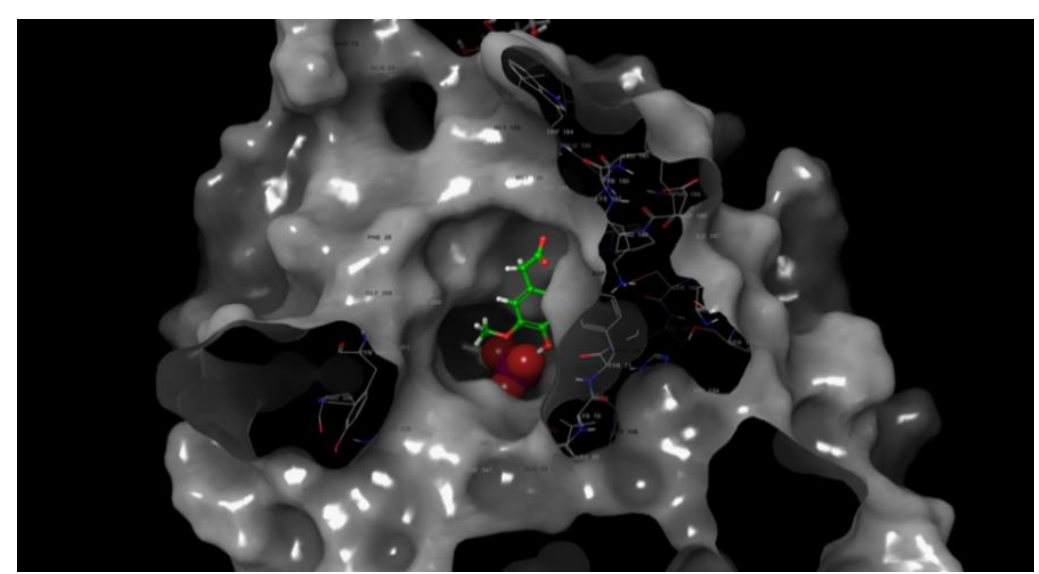

$\mathbf{a}$

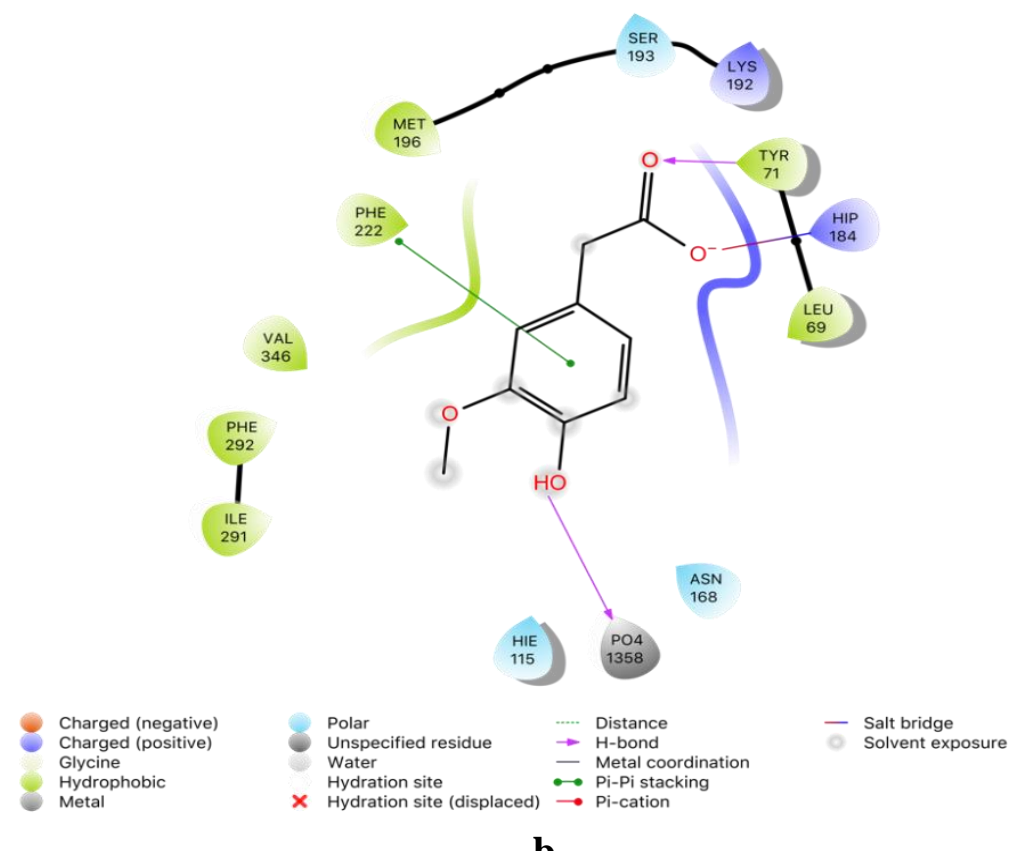

b

Figure 5. (a) Ligand interaction of homovanillic acid with 3SRE, (b) Glide docking image of homovanillic acid with 3 SRE 


\section{CONCLUSION}

In this study, PON1 was purified having a specific activity of $3945.15 \mathrm{EU} \mathrm{mg}^{-1}$ proteins, with a yield of $21.22 \%$ and 239-fold and determined that homovanillic acid and phloridzin dihydrate are potent inhibitors for PON1 enzyme. The most striking result to emerge from the data evaluation was that phenolic compounds concentrations used in the calculation of the $\mathrm{IC}_{50}$ values and $K_{i}$ constants in the assays were at the low levels. The findings of this research have a number of major implications for future practice.

\section{ACKNOWLEDGEMENT}

The author thanks Samet Karataş and Muhammed Kerem Türkeş for his kind help suggestions during the preparation of the manuscript. This work was supported by the Research Fund of Erzincan Binali Y1ldırım University (project number FBA-2017-501). The author is grateful to Erzincan Binali Yıldırım University for financial support.

\section{REFERENCES}

Akbaba Y, Türkeş C, Polat L, Söyüt H, Şahin E, Menzek A, Göksu S, Beydemir Ş, 2013. Synthesis and Paroxonase Activities of Novel Bromophenols. Journal of enzyme inhibition and medicinal chemistry, 28 (5): 1073-1079.

Alim Z, Beydemir Ş, 2016. Some Anticancer Agents Act on Human Serum Paraoxonase-1 to Reduce Its Activity. Chemical biology \& drug design, 88 (2): 188-196.

Alim Z, Kilic D, Koksal Z, Beydemir S, Ozdemir $\mathrm{H}$, 2017. Assessment of the Inhibitory Effects and Molecular Docking of Some Sulfonamides on Human Serum Paraoxonase 1. Journal of biochemical and molecular toxicology, 31 (10): e21950.

Alım Z, Kılıç D, Demir Y, 2018. Some indazoles reduced the activity of human serum paraoxonase 1, an antioxidant enzyme: in vitro inhibition and molecular modeling studies. Archives of physiology and biochemistry, 1-9.
Aslan HE, Demir Y, Özaslan MS, Türkan F, Beydemir Ş, Küfrevioğlu ÖI, 2018. The behavior of some chalcones on acetylcholinesterase and carbonic anhydrase activity. Drug and chemical toxicology, 1-7.

Beydemir Ş, Demir Y, 2017. Antiepileptic Drugs: Impacts on Human Serum Paraoxonase-1. Journal of biochemical and molecular toxicology, 31 (6): e21889.

Bradford MM, 1976. A Rapid and Sensitive Method for the Quantitation of Microgram Quantities of Protein Utilizing the Principle of Protein-Dye Binding. Analytical biochemistry, 72 (1-2): 248-254.

Cebeci B, Alim Z, Beydemir Ş, 2014. In Vitro Effects of Pesticide Exposure on the Activity of the Paraoxonase-1 Enzyme from Sheep Liver Microsomes. Turkish Journal of Chemistry, 38 (3): 512-520.

Copeland RA, 2004 Enzymes: A Practical Introduction to Structure, Mechanism, and Data Analysis. John Wiley \& Sons

Copeland RA, 2013 Evaluation of Enzyme Inhibitors in Drug Discovery: A Guide for Medicinal Chemists and Pharmacologists. John Wiley \& Sons

Costa LG, Li WF, Richter RJ, Shih DM, Lusis A, Furlong CE, 1999. The Role of Paraoxonase (Pon1) in the Detoxication of Organophosphates and Its Human Polymorphism. Chemico-biological interactions, 119: 429-438.

Ekinci D, Beydemir Ş, 2009. Evaluation of the Impacts of Antibiotic Drugs on Pon 1; a Major Bioscavenger against Cardiovascular Diseases. European journal of pharmacology, 617 (1-3): 84-89.

Ekinci D, Beydemir Ş, 2010. Purification of Pon1 from Human Serum and Assessment of Enzyme Kinetics against Metal Toxicity. Biological trace element research, 135 (1-3): 112-120.

Ekinci D, Şentürk M, Beydemir Ş, İrfan Küfrevioğlu Ö, Supuran CT, 2010. An Alternative Purification Method for Human Serum Paraoxonase 1 and Its Interactions with Sulfonamides. Chemical biology \& drug design, 76 (6): 552-558. 
Fraga CG, Galleano M, Verstraeten SV, Oteiza PI, 2010. Basic Biochemical Mechanisms Behind the Health Benefits of Polyphenols. Molecular aspects of medicine, 31 (6): 435445.

Friesner RA, Banks JL, Murphy RB, Halgren TA, Klicic JJ, Mainz DT, Repasky MP, Knoll EH, Shelley M, Perry JK, 2004. Glide: A New Approach for Rapid, Accurate Docking and Scoring. 1. Method and Assessment of Docking Accuracy. Journal of medicinal chemistry, 47 (7): 1739-1749.

Furlong CE (2008) Paraoxonases: An Historical Perspective The Paraoxonases: Their Role in Disease Development and Xenobiotic Metabolism. Springer, p 3-31

Furlong CE, Richter RJ, Seidel SL, Costa LG, Motulsky AG, 1989. Spectrophotometric Assays for the Enzymatic Hydrolysis of the Active Metabolites of Chlorpyrifos and Parathion by Plasma Paraoxonase/Arylesterase. Analytical biochemistry, 180 (2): 242-247.

Greenwood JR, Calkins D, Sullivan AP, Shelley JC, 2010. Towards the Comprehensive, Rapid, and Accurate Prediction of the Favorable Tautomeric States of Drug-Like Molecules in Aqueous Solution. Journal of computer-aided molecular design, 24 (6-7): 591-604.

Gutiérrez-Grijalva EP, Ambriz-Pére DL, LeyvaLópez N, Castillo-López RI, Heredia JB, 2016. Dietary Phenolic Compounds, Health Benefits and Bioaccessibility. Archivos latinoamericanos de nutricion, 66 (2).

Halgren TA, Murphy RB, Friesner RA, Beard HS, Frye LL, Pollard WT, Banks JL, 2004. Glide: A New Approach for Rapid, Accurate Docking and Scoring. 2. Enrichment Factors in Database Screening. Journal of medicinal chemistry, 47 (7): 1750-1759.

Hassett C, Richter RJ, Humbert R, Chapline C, Crabb JW, Omiecinski CJ, Furlong CE, 1991. Characterization of Cdna Clones Encoding Rabbit and Human Serum Paraoxonase: The Mature Protein Retains Its Signal Sequence. Biochemistry, 30 (42): 10141-10149.
Klaassen CD, Watkins JB, 1996 Casarett and Doull's Toxicology: The Basic Science of Poisons, vol 5. McGraw-Hill New York

Kontush A, Chapman MJ, 2006. Functionally Defective High-Density Lipoprotein: A New Therapeutic Target at the Crossroads of Dyslipidemia, Inflammation, and Atherosclerosis. Pharmacological reviews, 58 (3): 342-374.

Kuzu M, Kandemir FM, Yildirim S, Kucukler S, Caglayan C, Turk E, 2018. Morin attenuates doxorubicin-induced heart and brain damage by reducing oxidative stress, inflammation and apoptosis. Biomedicine \& Pharmacotherapy, 106: 443-453.

Laemmli UK, 1970. Cleavage of Structural Proteins During the Assembly of the Head of Bacteriophage T4. nature, 227 (5259): 680.

Lineweaver H, Burk D, 1934. The Determination of Enzyme Dissociation Constants. Journal of the American chemical society, 56 (3): 658-666.

Mackness MI, Arrol S, Abbott C, Durrington PN, 1993. Protection of Low-Density Lipoprotein against Oxidative Modification by High-Density Lipoprotein Associated Paraoxonase. Atherosclerosis, 104 (1-2): 129-135.

Mackness MI, Durrington PN, 1995. Hdl, Its Enzymes and Its Potential to Influence Lipid Peroxidation. Atherosclerosis, 115 (2): 243253.

Manach C, Williamson G, Morand C, Scalbert A, Rémésy C, 2005. Bioavailability and Bioefficacy of Polyphenols in Humans. I. Review of 97 Bioavailability Studies-. The American journal of clinical nutrition, 81 (1): 230S-242S.

Manco G, Porzio E, Suzumoto Y, 2018. Enzymatic detoxification: a sustainable means of degrading toxic organophosphate pesticides and chemical warfare nerve agents. Journal of Chemical Technology \& Biotechnology, 93: 2064-2082. 
Masumoto S, Akimoto Y, Oike H, Kobori M, 2009. Dietary Phloridzin Reduces Blood Glucose Levels and Reverses Sglt1 Expression in the Small Intestine in Streptozotocin-Induced Diabetic Mice. Journal of agricultural and Food Chemistry, 57 (11): 4651-4656.

Middleton E, Kandaswami C, Theoharides TC, 2000. The Effects of Plant Flavonoids on Mammalian Cells: Implications for Inflammation, Heart Disease, and Cancer. Pharmacological reviews, 52 (4): 673-751.

Pla A, Rodrigo L, Hernandez AF, Gil F, Lopez O, 2007. Effect of Metal Ions and Calcium on Purified Pon1 and Pon3 from Rat Liver. Chemico-biological interactions, 167 (1): 63-70.

Renault F, Chabrière E, Andrieu J-P, Dublet B, Masson P, Rochu D, 2006. Tandem Purification of Two Hdl-Associated Partner Proteins in Human Plasma, Paraoxonase (Pon1) and Phosphate Binding Protein (Hpbp) Using Hydroxyapatite Chromatography. Journal of Chromatography B, 836 (1-2): 15-21.

Robertson JG, 2005. Mechanistic Basis of Enzyme-Targeted Drugs. Biochemistry, 44 (15): 5561-5571.

Sastry GM, Adzhigirey M, Day T, Annabhimoju R, Sherman W, 2013. Protein and Ligand Preparation: Parameters, Protocols, and Influence on Virtual Screening Enrichments. Journal of computer-aided molecular design, 27 (3): 221-234.

Shelley JC, Cholleti A, Frye LL, Greenwood JR, Timlin MR, Uchimaya M, 2007. Epik: A Software Program for $\mathrm{Pk}$ a Prediction and Protonation State Generation for Drug-Like Molecules. Journal of computer-aided molecular design, 21 (12): 681-691.

Sinan S, Kockar F, Arslan O, 2006. Novel Purification Strategy for Human Pon1 and Inhibition of the Activity by Cephalosporin and Aminoglikozide Derived Antibiotics. Biochimie, 88 (5): 565-574.

Surh YJ, 1998. Cancer Chemoprevention by Dietary Phytochemicals: A Mechanistic Viewpoint. The Cancer journal, 11 (1): 6-10.
Teiber JF, Xiao J, Kramer GL, Ogawa S, Ebner C, Wolleb H, Carreira EM, Shih DM, Haley RW, 2018. Identification of Biologically Active $\delta$-lactone Eicosanoids as Paraoxonase Substrates. Biochemical and biophysical research communications, 505 (1): 87-92.

Tuck KL, Hayball PJ, 2002. Major Phenolic Compounds in Olive Oil: Metabolism and Health Effects. The Journal of nutritional biochemistry, 13 (11): 636-644.

Türkeş C, Soyut H, Beydemir S, 2013. Inhibition Effects of Gemcitabine Hydrochloride, Acyclovir, and 5-Fluorouracil on Human Serum Paraoxonase-1 (Hpon1): In Vitro. Open J Biochem, 1: 10-15.

Türkeş C, Söyüt H, Beydemir Ş, 2014. Effect of Calcium Channel Blockers on Paraoxonase1 (Pon1) Activity and Oxidative Stress. Pharmacological reports, 66 (1): 74-80.

Türkeş C, Söyüt H, Beydemir Ş, 2015. Human Serum Paraoxonase-1 (Hpon1): In Vitro Inhibition Effects of Moxifloxacin Hydrochloride, Levofloxacin Hemihidrate, Cefepime Hydrochloride, Cefotaxime Sodium and Ceftizoxime Sodium. Journal of enzyme inhibition and medicinal chemistry, 30 (4): 622-628.

Türkeş C, Söyüt H, Beydemir Ş, 2016. In Vitro Inhibitory Effects of Palonosetron Hydrochloride, Bevacizumab and Cyclophosphamide on Purified ParaoxonaseI (Hpon1) from Human Serum. Environmental toxicology and pharmacology, 42: 252-257.

Velderrain-Rodríguez GR, Palafox-Carlos H, Wall-Medrano A, Ayala-Zavala JF, Chen CO, Robles-Sánchez M, Astiazaran-García $\mathrm{H}$, Alvarez-Parrilla E, González-Aguilar GA, 2014. Phenolic Compounds: Their Journey after Intake. Food \& function, 5 (2): 189-197.

Wang Q, Qiu L, Chen X-r, Song K-K, Shi Y, Chen Q-X, 2007. Inhibitory Effects of Phloridzin Dihydrate on the Activity of Mushroom (Agaricus Bisporus) Tyrosinase. Bioorganic \& medicinal chemistry, 15 (3): 1568-1571. 